\title{
Myxoid and Lipomatous Solitary Fibrous Tumor of Soft Tissue: A Case Description
}

\author{
Javier Ortiz Rodríguez-Parets*, Cristina González Velasco, Elisa Muñoz Torres, \\ María Dolores Ludeña de la Cruz
}

Departamento de Anatomía Patológica, Hospital Universitario de Salamanca, Salamanca, Spain

Email: *jortiz@usal.es

How to cite this paper: Rodríguez-Parets, J.O., Velasco, C.G., Torres, E.M. and de la Cruz, M.D.L. (2017) Myxoid and Lipomatous Solitary Fibrous Tumor of Soft Tissue: A Case Description. Open Journal of Pathology, 7, 20-24.

http://dx.doi.org/10.4236/ojpathology.2017. $\underline{71003}$

Received: November 14, 2016

Accepted: January 3, 2017

Published: January 6, 2017

Copyright $\odot 2017$ by authors and Scientific Research Publishing Inc. This work is licensed under the Creative Commons Attribution International License (CC BY 4.0).

http://creativecommons.org/licenses/by/4.0/

(c) (i) Open Access

\begin{abstract}
We present a case of a myxoid and lipomatous solitary fibrous tumor that was observed in a 67-year-old man. The tumor, which had a maximum diameter of $10 \mathrm{~cm}$, was located in the soft tissues of the dorsal region and appeared macroscopically well delimited and encapsulated. Upon cutting, a markedly gelatinous internal surface was observed. A microscopic study revealed an intense and diffusely myxoid neoplasia, with small areas of adipose aspect, in which histological (staghorn vessels, perivascular hyalinization, fusiform cells of benign aspect) and immunohistochemical (intensive positivity for $\mathrm{CD} 34, \mathrm{Bcl}-2$ and $\mathrm{Cd} 99$ and negativity for muscle markers) data were consistent with a solitary fibrous tumor were observed. To conclude, the main characteristics of this lesion are discussed, and a differential diagnosis is established with other entities.
\end{abstract}

\section{Keywords}

Solitary Fibrous Tumor, Myxoid and Lipomatous Differentiation, Histopathology, Immunohistochemistry

\section{Introduction}

The constant development of oncology and all of the branches of medicine involved in the treatment of cancer have led to the introduction of increasingly effective and personalized modern therapies in which exact knowledge of the tumor is of great importance. As a result, we pathologists find ourselves obliged to make increasingly accurate diagnoses, and therefore, to exhaustively determine neoplastic pathology, both of more frequent cases and of those variants are rarely observed in daily clinical practice.

Based on this affirmation, we were encouraged to present the case set forth below: A myxoid and lipomatous solitary fibrous tumor. A rare histological variant, rarely described in the medical literature, was observed in a 67-year-old man. 


\section{Clinical Case}

A 67-year-old man, without a history of interest, came to our hospital because of a slow-growing tumor that was located in the dorsal region and had increased in size in recent months.

Radiological studies revealed the solid character of the lesion, its good delimitation and its superficial intramuscular location.

Once completely removed, an irregularly elongated tumor was observed that was apparently well delimited and encapsulated; it was of soft consistency and reached a maximum diameter of $10 \mathrm{~cm}$. Upon cutting, its marked gelatinous aspect was evident (Figure 1).

A histological study showed an markedly myxoid neoplasia, of low cell density, in which the presence of abundant elongated and branched vessels (staghorn vessels) were noted. Neoplastic cells were of a homogenous and fusiform appearance; benignity was suggested because mitosis was not observed. After extensive sampling, small occasional pockets of adipose cells were observed (Figure 2).

An immunohistochemical study demonstrated intense and diffuse positivity of the cancer cells for CD34, CD99, Bcl-2, EMA and vimentin; moreover, it was negative for actin, desmin, H-caldesmon and MyOD1. S100 staining showed only positivity in adipose cells. The proliferative activity (MIB-I) was lower than 1\% (Figure 3).

Based on these findings, our diagnosis was of myxoid and lipomatous solitary fibrous tumor (hemangiopericytoma).

Two years after its removal, no signs of recurrence or metastasis are observed

\section{Discussion}

Since its first description at the pleural level [1], solitary fibrous tumor has been a constantly expanding entity, both because it has been observed in multiple extrapleural

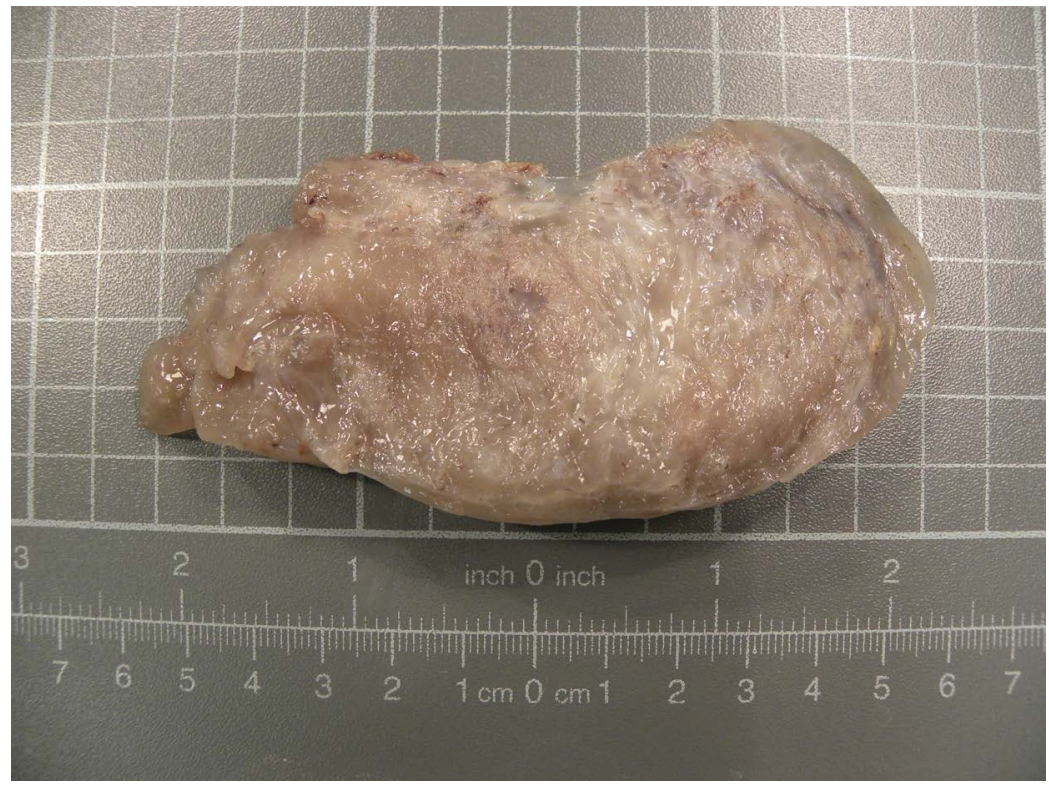

Figure 1. Myxoid and lipomatous SFT (Macros): Note the good delineation of the tumor and its gelatinous appearance. 


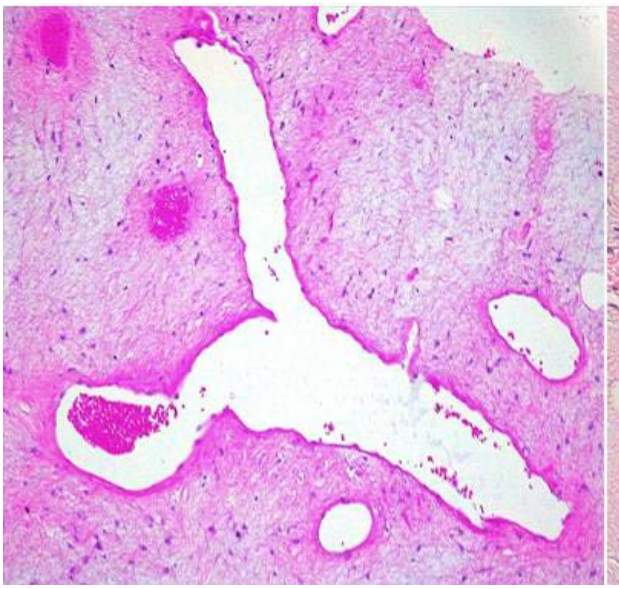

(a)

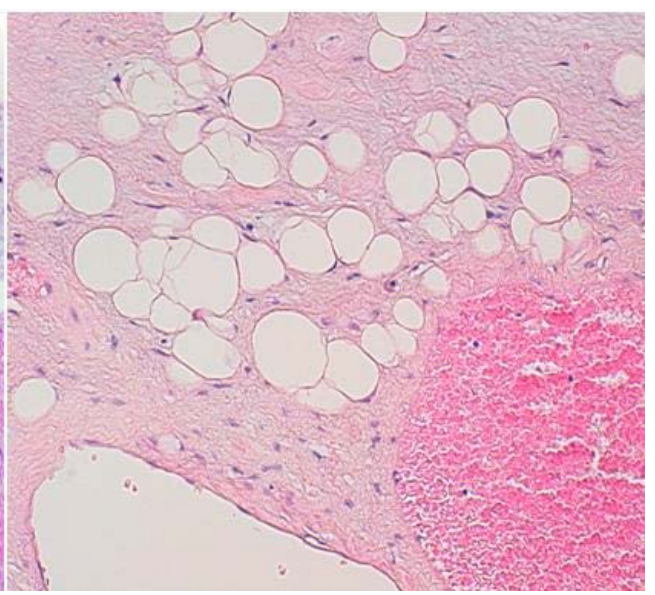

(b)

Figure 2. Myxoid and lipomatous SFT: Neoplasia markedly myxoid with staghorn vessels (a) and occasional fat cells (b). ((a) HE×100), ((b) HE×400).

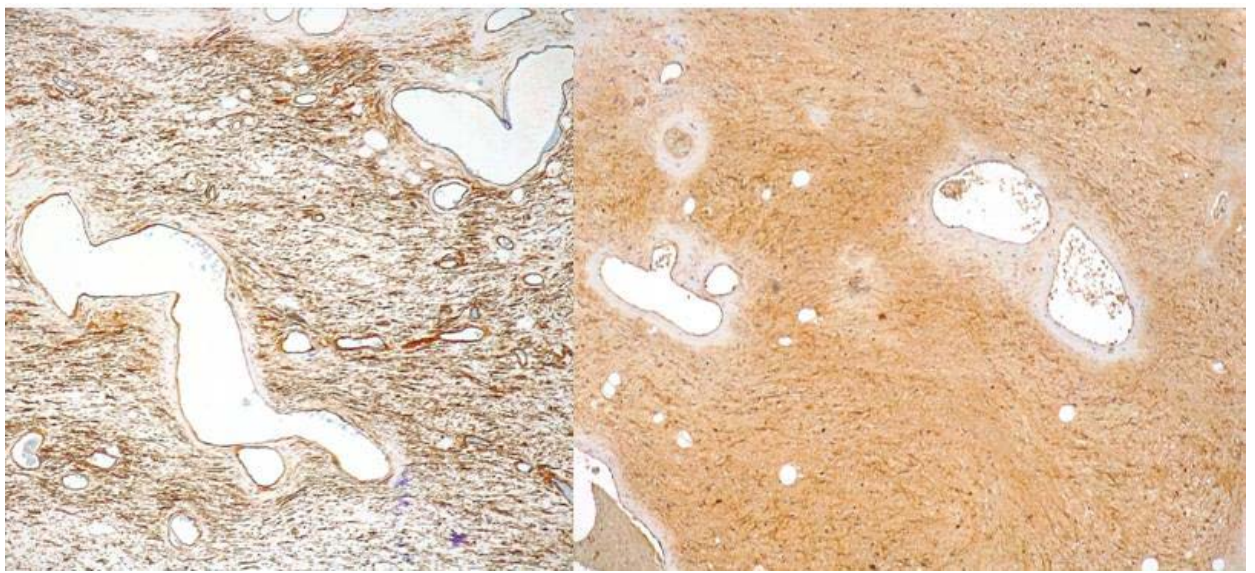

(a) (b)

Figure 3. Myxoid and lipomatous SFT: Positivity of tumor cells for CD34 (a) and CD99 (b) ((a) and (b) $\mathrm{IH} \times 50)$.

locations [2] [3] and because of its ability to include lesions that traditionally had received other denominations. Examples of the latter include angiofibroma of giant cells, which is a neoplasm that is generally located in the orbital region [4], and hemangiopericytoma, or its variant lipomatous hemangiopericytoma, which is primarily located in soft tissues [5] [6]. A thorough review of these entities, based on the study of their clinical behavior and ultrastructural and immunohistochemical properties, have led most authors to consider them as variants of the solitary fibrous tumor; thus, its old nomenclature has become obsolete [7] [8].

In our case, we are facing a soft tissue tumor with typical hemangiopericytomatous vascularization (staghorn vessels) and cellularity of benign appearance, whose immunohistochemical profile (CD34+, CD99+, Bcl-2+, EMA+, actin-) is completely consistent with a solitary fibrous tumor [9]. In our view, the most striking feature of this tumor was its marked and diffuse myxoid character and, to a lesser degree, its focal adipose differentiation. 
This myxoid change, which can be observed locally in many cases, takes on exceptional character when it is as intense as the tumor in this study [10] and is also accompanied by areas of lipomatous aspect. This appearance can cause diagnostic uncertainty, requiring the pathologist to make a differential diagnosis with other entities [11] [12]. Thus, in our example, it was necessary, together with extensive sampling of the piece to confirm the myxoid character of the lesion over its entire surface, to establish a differential diagnosis with entities such as intramuscular myxoma (absence of prominent vessels, CD34-), angiomyxolipoma (larger amount of adipose tissue, CD34-), myxoid liposarcoma (larger proportion of adipose tissue, presence of lipoblasts, CD34-), myxofibrosarcoma (histological aggressiveness, CD34-, absence of prominent vessels), muscular tumors (leiomyoma and leiomyosarcoma) with myxoid differentiation (CD34-, actin+, desmin+), nerve tumors (neurofibroma, nerve sheath myxoma) that are positive for S100, pleomorphic hyalinizing angiectactic tumor (pleomorphism, CD99-, Bcl-2-) or myxoid chondrosarcoma (CD34-, absence of prominent vessels, cellularity in rows).

Molecular analyses have discovered that almost all SFTs harbor an NAB2-STAT6 fusion gene, which is considered specific to this tumor type and recent

Studies have suggested that nuclear STAT6 immunoreactivity is a highly sensitive and specific marker of SFTs and can be helpful when diagnosis is inconclusive by conventional methods [13].

Once the nature of the neoplasm was established (solitary fibrous tumor), both its macroscopic appearance (good delimitation) and microscopic features (absence of necrosis and mitosis, low proliferative index and absence of cytologic atypia) were indicative elements of a favorable prognosis.

The clinical evolution confirms, for the moment, the histological findings. Two years after its removal, no signs of recurrence or metastasis are observed and the patient shows a good general condition, Behavior similar to that described by other authors, in cases histologically similar to ours.

\section{Conclusion}

Finally, we briefly emphasize the importance both for clinicians and pathologists to study, stay up to date and continue their ongoing collaboration because these are key elements for proper patient care.

\section{References}

[1] Klemperer, P. and Rabin, C.B. (1931) Primary Neoplasms of the Pleura. A Report of Five Cases. Archives of Pathology, 11, 385-412.

[2] Moszynski, R., Szubert, S., Tomczak, D., Saad, A., Samulak, D., Sajdak, S. and Szpurek, D. (2016) Solitary Fibrous Mass of the Omentum Mimicking an Ovarian Tumor: Case Report. European Journal of Gynaecological Oncology, 37, 144-147.

[3] Zhou, Y., Zheng, J., Zhu, Q., Xia, W. and Bhagat, S.K. (2016) Solitary Fibrous Tumor of the Salivary Gland: A Case Report. Oncology Letters, 11, 901-903.

[4] Furusato, E., Valenzuela, I.A., Fanburg-Smith, J.C., Auerbach, A., Furusato, B., Cameron, J.D. and Rushing, E.J. (2011) Orbital Solitary Fibrous Tumor: Encompassing Terminology for Hemangiopericytoma, Giant Cell Angiofibroma, and Fibrous Histiocytoma of the Orbit: Reappraisal of 41 Cases. Human Pathology, 42, 120-128. 
https://doi.org/10.1016/j.humpath.2010.05.021

[5] Routray, S., Mohanty, N., Panda, S. and Sahoo, S.R. (2015) Hemangiopericytoma/Solitary Fibrous Tumor of Mandible: A Rare Entity. Journal of Oral and Maxillofacial Pathology, 19, 260-262. https://doi.org/10.4103/0973-029X.164546

[6] Madala, J., Guttikonda, V.R. and Korlepara, R. (2015) Lipomatous Hemangiopericytoma in a Child: A Case Report with Immunohistochemical Evaluation. Journal of Oral and Maxillofacial Pathology, 19, 92-96. https://doi.org/10.4103/0973-029X.157209

[7] Pitchamuthu, H., Gonzalez, P., Kyle, P. and Roberts, F. (2009) Fat-Forming Variant of Solitary Fibrous Tumour of the Orbit: The Entity Previously Known as Lipomatous Haemangiopericytoma. Eye (Lond), 23, 1479-1481. https://doi.org/10.1038/eye.2008.215

[8] Lee, J.C. and Fletcher, C.D. (2011) Malignant Fat-Forming Solitary Fibrous Tumor (So-Called "Lipomatous Hemangiopericytoma"): Clinicopathologic Analysis of 14 Cases. The American Journal of Surgical Pathology, 35, 1177-1185. https://doi.org/10.1097/PAS.0b013e318219cd0b

[9] Carlos, R., de Andrade, B.A., Canedo, N.H., Abrahão, A.C., Agostini, M., de Almeida, O.P. and Romañach, M.J. (2016) Clinicopathologic and Immunohistochemical Features of Five New Cases of Solitary Fibrous Tumor of the Oral Cavity. Oral Surgery, Oral Medicine, Oral Pathology, Oral Radiology, 121, 390-395. https://doi.org/10.1016/j.oooo.2015.11.001

[10] Dantey, K. and Cooper, K. (2013) Myxoid Solitary Fibrous Tumor: A Study of Three Cases. International Journal of Surgical Pathology, 21, 358-362.

https://doi.org/10.1177/1066896912470166

[11] Lau, S.K., Weiss, L.M. and Chu, P.G. (2009) Myxoid Solitary Fibrous Tumor: A Clinicopathologic Study of Three Cases. Virchows Archiv, 454, 189-194. https://doi.org/10.1007/s00428-008-0721-7

[12] Lee, J.Y., Park, S.E., Shin, S.J., Kim, C.W., Kim, S.S. and Kim, K.H. (2015) Solitary Fibrous Tumor with Myxoid Stromal Change. The American Journal of Dermatopathology, 37, 570-573. https://doi.org/10.1097/DAD.0000000000000154

[13] Magro, G., Angelico, G., Leone, G. and Palazzo, J. (2016) Solitary Fibrous Tumor of the Breast: Report of a Case with Emphasis on Diagnostic Role of STAT6 Immunostaining. Pathology - Research and Practice, 212, 463-467. https://doi.org/10.1016/j.prp.2015.12.013

\section{Submit or recommend next manuscript to SCIRP and we will provide best service for you:}

Accepting pre-submission inquiries through Email, Facebook, LinkedIn, Twitter, etc. A wide selection of journals (inclusive of 9 subjects, more than 200 journals)

Providing 24-hour high-quality service

User-friendly online submission system

Fair and swift peer-review system

Efficient typesetting and proofreading procedure

Display of the result of downloads and visits, as well as the number of cited articles

Maximum dissemination of your research work

Submit your manuscript at: http://papersubmission.scirp.org/

Or contact ojpathology@scirp.org 